Goldschmidt 2021 Abstract

https://doi.org/10.7185/gold2021.3722

\section{The concentration of organic compounds in high-pH waters of serpentinizing environments determined by 1H NMR: continental sites (Oman, Liguria, New Caledonia, Portugal) and a marine environment (Marianna mud volcanoes: IODP Exp 366, ODP Legs 125 and 195)}

CHRISTOPHE MONNIN ${ }^{1}$, OLIVIER SISSMANN ${ }^{2}$, GILLES BERGER $^{3}$, MARIANNE QUÉMÉNEUR ${ }^{4}$, ROY PRICE ${ }^{5}$, BERNARD PELLETIER $^{6}$, JOSÉ MARQUÈS ${ }^{7}$ AND CHARLES GEOFFREY WHEAT ${ }^{8}$

${ }^{1}$ Geosciences Environnement Toulouse (CNRS/UPS/IRD/CNES)

${ }^{2}$ IFP energies nouvelles

${ }^{3}$ IRAP (CNRS/UPS)

${ }^{4}$ Aix Marseille Université, Mediterranean Institute of Oceanography, CNRS/IRD, UMR7294

${ }^{5}$ SUNY Stony Brook/School of Marine and Atmospheric

Sciences

${ }^{6}$ Centre IRD de Nouméa

${ }^{7}$ Centro de Recursos Naturais e Ambiente, Universidade de Lisboa

${ }^{8}$ Institute of Marine Sciences, College of Fisheries and Ocean Sciences, University of Alaska

Presenting Author: christophe.monnin@get.omp.eu

The very alkaline waters produced by low temperature serpentinization of ultramafic rocks may contain elevated concentrations of dissolved organic carbon likely to act as a substrate for microbial life. High-pH (up to 11.7) waters collected at on-land sites (Oman, Liguria, New Caledonia, Portugal) and porewaters ( $\mathrm{pH}$ up to 12.5) collected in boreholes drilled during IODP Exp 366 in three Marianna forearc mud volcanoes (Yinazao, Fantangisña and Asùt Tesoru) have been analyzed for organic compounds using ${ }^{1} \mathrm{H}$ NMR spectroscopy. Whereas the waters collected at continental sites are devoid of organics, very high concentrations of acetate (up $80 \mu \mathrm{mol} / \mathrm{L}$ ), formate (up to $250 \mu \mathrm{mol} / \mathrm{L}$ ), ethanol (up to $700 \mu \mathrm{mol} / \mathrm{L}$ ), methanol (up to $300 \mu \mathrm{mol} / \mathrm{L}$ ) and acetonitrile (up to $40 \mu \mathrm{mol} / \mathrm{L}$ ) are found in porewaters collected in boreholes located at the summits of Yinazao and Asùt Tesoru, and on the flank of Fantangisña. On the contrary, porewater samples collected in other boreholes where the $\mathrm{pH}$ is around 8 do not contain these organic molecules, but do show noticeable amounts of acetate (up to $120 \mu \mathrm{mol} / \mathrm{L}$ ) and formate (up to $50 \mu \mathrm{mol} / \mathrm{L}$ ). When reported versus $\mathrm{pH}$, the (inorganic and organic) porewater composition data including those for Conical (ODP Leg 125) and South Chamorro (ODP Leg 195) seamounts show evidence of a $\mathrm{pH}$ threshold around 11.5 above which all molecules or compounds usually involved in organic matter degradation (acetate, formate, ethanol, methanol, acetonitrile, dissolved ammonium) show similar variations in concentration at almost constant $\mathrm{pH}$. The discrepancy between DOC contents directly measured with the carbon elemental analyzer and those obtained from the sum of organics may be attributed to the loss of volatile organics during the $\mathrm{CO}_{2}$ purge following sample acidification in standard DOC measurements.

It may be speculated that the origin of these organic molecules is the degradation of organic matter of sedimentary origin at high $\mathrm{pH}$ and not necessarily their abiotic formation from an inorganic carbon source (such as the reduction of $\mathrm{CO}_{2}$ ). 